\title{
Taraftarların Takımlarla Özdeşleşme Düzeylerinin, Takımların Lisanslı Ürünlerine Yönelik Kalite Algısı ve Satın Alma Niyetine Etkisi
}

\author{
The Effect of Spectators' Level of Identification with Their Favorite Sports Teams on Their \\ Perceived Quality and Purchase Intentions of Team-Licensed Products
}

Ömer TORLAK ${ }^{1}$, Behçet Yalın ÖZKARA², Volkan DOĞAN³

\begin{abstract}
ÖZET
Bu çalışmanın amacı, taraftarların takımlarla özdeşleşme düzeylerinin, tuttukları takımların lisanslı ürünlerine yönelik kalite algısına ve satın alma niyetine olan etkisini incelemektir. Çalışmada kolayda örnekleme yöntemi uygulanmış olup, araştırmanın verileri Eskişehir Osmangazi Üniversitesi ve Anadolu Üniversitesi öğrencilerinden elde edilmiştir. Çalışmada elde edilen 314 veri, AMOS 16.0 paket programı aracılığıyla yapısal eşitlik modellemesi ile analiz edilmiştir. Araştırma sonuçları taraftarların takımlarla özdeşleşme düzeylerinin, hem tuttukları takımların lisanslı ürünlerini satın alma niyetleri üzerinde hem de tuttukları takımların lisanslı ürünlerine yönelik kalite algıları üzerinde pozitif yönde anlamlı etkileri olduğuna işaret etmektedir. Ayrıca elde edilen bulgular, taraftarların tuttukları takımların lisanslı ürünlerini satın almalarına yönelik niyetleri üzerinde, takımları ile özdeşleşme düzeylerinin, lisanslı ürünlere yönelik kalite algılarından daha fazla etkiye sahip olduğunu göstermektedir.
\end{abstract}

Anahtar Kelimeler: Taraftar özdeşlik düzeyi, kalite algısı, satın alma niyeti.

\section{GíRiş}

Uydu alıcılar, internet, dijital yayınlar ve bilişim teknolojilerindeki diğer gelişmeler spor endüstrisinin hızla globalleşmesini sağlamıştır (Daniel, 1999). Günümüzde spor endüstrisinin globalleşmesinin bir sonucu olarak (Eucher, 1993), uluslararası başarılara imza atabilen spor kulüpleri dünyanın dört bir tarafındaki pazarlara rahatlıkla erişim sağlayabilmektedir.

Tüm bu olanakların katkısı ile birlikte, futbola ilişkin aktivitelere doğrudan katılım gösteren birey sayısı yaklaşık 250 milyon civarındayken, futbola ilgi duyan ve futbol aktivitelerini takip eden kişi sayısının ise yaklaşık 1.4 milyar olduğu düşünülmektedir. Sadece dünya kupası finalini

\begin{abstract}
The aim of this study is to determine the effect of fans' level of identification with their favorite sports teams on their perceived quality and purchase intentions of team-licensed products. The research data were obtained from Eskisehir Osmangazi University students and Anadolu University students by using convenience sampling method. A total of 314 data obtained in this study, were analyzed by means of AMOS 16.0 with structural equation modeling. The results showed that fans' level of identification with their favorite sports teams had a significant positive impact on both their purchase intentions and perceived quality of their favorite sports teams'licensed products. On the other hand, the results revealed that fans' level of identification with their favorite sports teams had more effect on their purchase intentions of their favorite sports teams' products than their perceived quality of team-licensed products.
\end{abstract}

Keywords: Spectator identification level, perceived quality, purchase intention.

canlı olarak televizyonlardan izleyen kişi sayısı ise 33 milyonu bulmaktadır (Giulianotti ve Robertson, 2004). Aşçı (2009)'nın da belirttiği üzere 120 binden fazla lisanslı oyuncusu ile futbol, dünyanın en popüler sporu olarak karşımıza çıkmaktadır. 2001 yılındaki futbolcu transferlerinin toplam parasal değeri 250 milyar poundu bulmaktadır ki bu rakam; Hollanda'nın gayri safi yurt içi hasılasından daha yüksektir (Walvin, 2001). Tüm bu çarpıcı rakamların da gösterdiği üzere spor endüstrisi önemli ticari iş kollarından biri olarak karşımıza çıkmaktadır. Antik olimpiyatlardan beri satılan spor ürünleri de(Aytaç, 2009), günümüzde hızla globalleşen, büyüyen ve ekonomik önemi de bu büyüme ile birlikte her geçen gün artan bir pazarda yer almaktadır. Nitekim Manchester United spor kulübü artık sadece İngiltere'de değil, Asya'dan

\footnotetext{
' Prof. Dr., KTO Karatay Üniversitesi, İktisadi ve İdari Bilimler Fakültesi, İ̧̧letme Bölümü, omer.torlak@karatay.edu.tr

${ }^{2}$ Araş. Gör., Eskişehir Osmangazi Üniversitesi, İktisadi ve İdari Bilimler Fakültesi, İșletme Bölümü, bozkara@ogu.edu.tr

${ }^{3}$ Araş. Gör., Eskişehir Osmangazi Üniversitesi, İktisadi ve İdari Bilimler Fakültesi, İ̧̧letme Bölümü, vodogan@ogu.edu.tr
} 
Avrupa'ya dünyanın bir çok yerinde satış mağazaları olan bir futbol kulübüdür.

Günümüz koşullarında spor kulüpleri ayakta kalabilmek adına sportif başarılarını ticarileştirmek zorundadırlar. $\mathrm{Bu}$ noktada sportif başarının ticarileştirilmesinde en çok başvurulan yol, lisanslı ürünlerin satışıdır. Ülkemize baktığımızda Türkiye Süper Ligi'ndeki 18 takımın lisanslı ürünlerden elde ettiği gelir ölçütüne göre yapılan sıralamada Avrupa'da altıncı sırada yer aldığı görülmektedir (European Football Merchandising Report, 2010). Türkiye'de 3 büyüklerin lisanslı ürün satışlarının cirosu yıllık yaklaşık 54 milyon Euro'yu bulmakla beraber (European Merchandising Report, 2010) sadece Real Madrid'in 2004 sezonunda bir futbolcusu olan Beckham'ın formalarının satışından elde ettiği ciro yaklaşık 41 milyon Euro'dur (Aytaç, 2009). Real Madrid'in lisanslı ürün satışlarından elde ettiği gelir diğer tüm gelir kaynaklarından elde ettiği gelirden daha fazladır (The National Post, 2004). Rakamların da gösterdiği üzere, sportif başarıların ticarileştirilmesinde spor kulüplerinin en önemli gelir kaynağını lisanslı ürünler oluşturmaktadır (Hinckley, 2004; Kolah, 2005). Dolayısıyla, spor kulüpleri de potansiyel müşterileri olarak gördükleri taraftarlarının isteklerine cevap verecek ürünler üretme yarışına girmektedirler. Bu ürünlerin bir kısmını kendileri üretirken, bir kısmını da lisans bedeli karşılığı başka firmalara ürettirmektedirler. Örneğin dünyanın en değerli takımı olan Manchester United'ın lisanslı ürünleri ev kredisine kadar uzanan bir çeşitliliğine sahipken, Türk takımlarının ürün çeşitliliği kozmetik, tekstil ve hediyelik eşya gibi ürünler ile sınırlı kalmaktadır (Yavaş, 2005). Benzer şekilde Galatasaray'ın 2000 yılında UEFA ve Süper Kupayı kazanarak imza attığı sportif başarılara rağmen bu başarıların ticarileştirilmesi noktasında başarısız kaldığı düşünülmektedir. Dolayısıyla sadece sportif başarıların değil bu başarıların ticari olarak kazanca çevrilmesinin de önem arz ettiği söylenebilir.

Hızla büyüyen spor pazarında kulüpler, rakiplerinin önüne geçebilmek için sahip oldukları gelir kaynaklarını arttırmak zorundadırlar. Bunun için, spor şirketlerinin ekonomik varlığının garantisi olan taraftarlara (Erdoğan, 2008) değer yaratmaları gerekmektedir (Gencer ve Aycan, 2008). Hem taraftar hem de kulüpler için değer yaratmanın en etkin yollarından birisi de lisanslı ürünler olarak karşımıza çıkmaktadır. Lisanslı ürünler sayesinde kulüpler gelir elde ederken, taraftarlar da takımlarıyla olan duygusal bağlarını geliştirebilmektedirler. Nitekim konuya ilişkin araştırmalarda göstermektedir ki, takımla özdeşleşme düzeyinin kulübün ekonomik varlığını sürdürmede ve güçlendirmede önemli etkisi bulunmaktadır (Aycan vd., 2009). Bu bağlamda spor kulüplerinin ve lisanslı ürün üreten işletmelerin, taraftarların satın alma davranışlarını anlayabilmeleri ve pazarlama stratejilerini bu doğrultuda belirlemeleri önem arz etmektedir.

Bu çerçevede çalışmanın amacı, lisanslı ürünlere yönelik kalite algısı ve satın alma niyeti üzerinde, taraftarların özdeşleşme düzeylerinin anlamlı bir etkisinin olup olmadığını ortaya koymaktır. Yapılan literatür incelemesi sonucunda, taraftar özdeşlik düzeyi ile lisanslı ürünlerin kalite algısı arasındaki ilişkiye yönelik herhangi bir çalışmaya rastlanamamıştır. Bu bağlamda çalışmanın, hem bu ilişkinin ortaya konması hem de lisanslı ürünlere yönelik olarak algılanan kalite ve taraftar özdeşlik düzeyinin satın alma niyeti üzerindeki etkilerinin karşılaştııılması bağlamında literatüre anlamlı bir katkı sağlayabileceği düşünülmektedir.

\section{KAVRAMSAL ÇERÇEVE}

Günümüzde spor endüstrisinin ekonomik niceliği dikkat çekici boyutlara ulaşmıştır. Ancak her ne kadar pazarlama açısından lisanslı ürünlerin önemi hızla artıyor olsa da, bu konuya ilişkin akademik çalışmaların yeterli düzeye ulaştığını söylemek oldukça zordur (Ferrand ve Pages, 1999).

Lisans, bir organizasyonun bir başka organizasyona marka ismini, patentini, ticari sırrını ve diğer imkanlarını bir ücret veya imtiyaz karşıığı kullanma yetkisi vermesi olan bir anlaşma biçimidir (Argan, 2008). Günümüzde spor kulüpleri de lisans bedeli karşılığında isim haklarını satabilmektedirler. Kulüpler lisans anlaşması çerçevesinde işletmelere patent, telif, tasarım, pazarlama teknikleri, marka gibi sahip olduğu haklarının kullanım hakkını verebilmektedirler (Aytaç, 2009). Dolayısıyla lisanslı spor ürünleri, bu hakların kullanımı sayesinde işletmeler tarafından üretilen, ilgili takımın ismini, logosunu taşıyan ürünler olarak karşımıza çıkmaktadır.

Bireyin bilinçli bir şekilde satın alma çabası olan satın alma niyetinin (Spears ve Singh, 2004) önemli belirleyicilerinden biri kalite algısıdır (Tsiotsou, 2006). Crosby'nin (1979) bir ürünün gerekliliklere uygunluk derecesi olarak tanımlamış olduğu kalite kavramına ilişkin literatür incelendiğinde objektif kalite ile algılanan kalite arasında bir ayrımın ortaya konduğu görülmektedir (Garvin, 1983; Jacoby ve Olson, 1985; Mitra ve Golder, 2006).

Objektif kalite mekanik ve teknik olarak bir ürünün mükemmelliğine (Monroe ve Krishnan, 1985) dair iken, kalite algısı ise tüketicinin ürünü subjektif 
değerlendirmesine ilişkin bir kavramdır. Her ne kadar algılanan kalite tüketicinin zihnindeki subjektif bir değerlendirme olsa da, literatürde tüketicinin satın alma kararında algılanan kalitenin daha etkili olduğuna işaret eden sonuçlar ortaya konmuştur. (Aaker ve Jacobson, 1994; Zeithaml, 1998). Bu nedenle çalışmada objektif kalite yerine kalite algısının ele alınmasının daha uygun olacağı düşünülmektedir.

Spor taraftarları ile ilgili araştırmalarda, Wann (1997) tarafından psiko-sosyal Model içerisinde yer alan takımla özdeşleşme kavramı dikkat çekmektedir. Günay ve Tiryaki (2003), taraftar özdeşlik düzeyini bir taraftarın psikolojik olarak tuttuğu takımla ilgilenme düzeyi olarak tanımlamışlardır. Takımla özdeşleşme düzeyi yüksek olan bireyler, tuttukları takımların başarılarıyla sevinmekte, takımlarının kaybetmesi durumunda ise üzülmektedirler (Güllü ve Güçlü, 2006). Özdeşleşmenin bir başka önemli göstergesi de taraftarların takımlarını temsil eden renkleri ya da ürünleri; giydikleri, taşıdıkları, kullandıkları malzemeler üzerinde taşımalarıdır (Demirel vd., 2007). Taraftarlar takımlarına ait olan lisanslı spor ürünlerini bu şekilde kullanarak takımlarına olan bağlılıklarını gösterebilmektedirler (Kwak ve Kang, 2009). Tüm bunların yanı sıra Wann ve arkadaşlarının (2005) yaptıkları çalışmada taraftarların takımları ile özdeşleşmeleri sonucu kendilerine güven duygularının arttığı ve sosyalleşme düzeylerinde de artış olduğu tespit edilmiştir. Takımlar da satılan lisanlı ürünler vasıtası ile finansal gelir sağlayabilmektedirler. Dolayısıyla lisanslı spor ürünlerinin hem taraftar hem de spor kulübü için karşılıklı anlam ifade ettiği söylenebilir.

Shank (1999), spor ürününü "spor seyircisine, taraftarına ya da sponsoruna fayda sağlamak üzere tasarlanmış ürün, hizmet ya da ürün ve hizmetin birleşimi" şeklinde tanımlamıştır. Shank (1999)'a göre spor ürünleri öz ürün ve genişletilmiş ürün olmak üzere ikiye ayrılmaktadır. Öz ürün yapılan müsabaka ya da yarışmanın kendisi iken genişletilmiş ürün ise öz ürüne ilişkin olarak ortaya konan ürün, ikram, konaklama hizmetleri olmaktadır. Bu çalışmada, bir spor takımının logosunu, adını ya da bir başka markaya dair işaretini taşıyan ürünler olan lisanslı ürünler (Kwon, 2002) genişletilmiş ürünler olarak ele alınmıştır.

Taraftarlar takımlarına yönelik olarak güçlü duygusal bağlar oluşturmaktadırlar (Underwood vd., 2001). Lisanslı ürünler de taraftarlar için takımları ile bağ kurmanın biryolu olup (Fisher ve Wakefield, 1998), kulüpler için de önemli bir gelir kaynağı sağlamaktadır. Demirel ve arkadaşlarının (2007) yapmış oldukları çalışmada, takımla özdeşleşme düzeyinin kulübün varlığını sürdürmede ve güçlendirmede önemli etkisi olduğuna işaret eden sonuçlara ulaşmıştır.

\section{ARAŞTIRMANIN AMACI, ÖNEMI VE HIPOTEZLERI}

Lisanslı spor ürünleri pazarının kendine özgü bir doğası bulunmaktadır (Daniel, 1999). Dolayısıyla spor kulüplerinin ve lisanslı ürün üreten işletmelerin, taraftarların satın alma davranışlarını bu bağlam içerisinde anlayabilmeleri ve stratejilerini bu doğrultuda belirlemeleri önem arz etmektedir. Underwood ve arkadaşlarının (2001) yaptıkları çalışmada, taraftarların takımları ile aralarında çok güçlü duygusal bağlar oluşturduklarını tespit etmişlerdir. Dolayısıyla spor kulüpleri güçlü markalar ile taraftarların bağlılıklarının gelişmesini ve güçlenmesini sağlarken, aynı zamanda gelirlerini de arttırabileceklerdir (Burton ve Howard, 1999; Gustafson, 2001). Doğru pazarlama stratejilerini izleyen spor kulüplerinin taraftarlarını memnun ederken aynı zamanda kendi gelirlerini arttırabilecekleri yani kazan-kazan (win-win) şartlarını sağlayabilecekleri en etkili yollardan birisi lisanslı ürünlerin satışıdır.

Ülkemizde, genelde spor pazarlamasının ve özelde lisanslı ürün alanında yapılan araştırmaların kısıtlı olduğu göz önünde bulundurulduğunda, yapılacak olan bilimsel araştırmaların önemi katlanarak artmaktadır (Argan ve Katırcl, 2008).

Tüketicilerin ürünlere yönelik kalite algısı, ürünü satın alma kararı üzerinde önemli etkiye sahip olan faktörlerden biri olarak karşımıza çıkmaktadır. Tüketici kaliteli olduğunu düşündüğü ürüne yönelik pozitif bir tutum içerisine girmektedir. Yapılan çalışmaların da işaret ettiği üzere (Boulding vd., 1993; Parasuraman vd., 1996; Tsiotsou, 2006) kalite algısının satın alma niyeti üzerinde pozitif yönde bir etkiye sahip olduğu bilinmektedir. Literatürde yer alan çalışmaların işaret ettiği bu durumun benzer şekilde, taraftarların, lisanslı spor ürünlerini satın alma niyeti içinde geçerli olacağı düşünülmektedir.

$\mathrm{H}_{1}$ : Lisanslı ürünlere yönelik kalite algısı, lisanslı ürün satın alma niyeti üzerinde pozitif yönde anlamlı bir etkiye sahiptir.

Taraftarların takımlarıyla özdeşleşme düzeylerinin, takımlarının lisanlı ürünlerine yönelik algıları ve tutumları üzerinde etkisi olduğu bilinmektedir. Örneğin yapılan çalışmalar, taraftarların özdeşleşme düzeylerinin, markaya yönelik tutum (Dees vd., 2010) ve marka imajı algısı (Bauer vd., 2008) üzerinde pozitif yönde anlamlı etkileri olduğunu göstermektedir. Benzer şekilde Harolle ve arkadaşları (2009) 
tarafından yapılan çalışmada taraftarların özdeşlik düzeylerinin satın alma niyeti üzerinde anlamlı etkileri olduğuna işaret eden sonuçlara ulaşılmıştır. Literatürde yer alan ve daha önce bahsedildiği üzere kalite algısının, satın alma niyeti üzerinde anlamlı etkileri olduğu bilinmektedir. Bu bilgilerden yola çıkarak, taraftar özdeşlik düzeyi ve kalite algısının, satın alma niyetinin öncülleri olduğu söylenebilir. Yapılan literatür incelemesi kapsamında taraftarların tuttukları takımların lisanlı ürünlerini satın alma niyetinin öncülleri olan, taraftar özdeşlik düzeyi ve lisanlı ürünlere yönelik kalite algısı arasındaki ilişkiyi ortaya koyan herhangi bir çalışmaya rastlanmamıştır. Taraftarların özdeşlik düzeyinin, lisanslı ürünlere yönelik kalite algısı üzerinde pozitif yönde anlamlı bir etkiye sahip olacağı düşünülmektedir. Bu bağlamda araştırmanın ikinci hipotezi şu şekilde belirlenmiş̧ir:

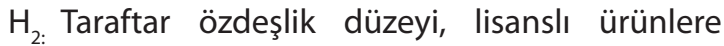
yönelik kalite algısı üzerinde pozitif yönde anlamlı bir etkiye sahiptir.

Taraftarların takımlarıyla olan özdeşleşme düzeylerinin önemli göstergelerinden birisi de, taraftarların takımlarını temsil eden ürünleri giydikleri, taşıdıkları, kullandıkları malzemeler üzerinde taşımaları olarak karşımıza çıkmaktadır (Demirel vd., 2007). Dolayısıyla takımıyla özdeşleşme düzeyi yüksek olan bir taraftarın takımının lisanslı ürünlerini satın almaya daha yatkın olacağı düşünülmektedir. Aynı zamanda taraftar özdeşlik düzeyi yüksek olan bireyler takımlarının lisanslı ürünlerine hayatlarının birçok alanında kullanarak takımlarına olan bağlılıklarını gösterebilmektedirler (Kwak ve Kang, 2009). Bununla beraber, Harolle ve arkadaşları (2009) yaptıkları çalışmada, taraftarların özdeşleşme düzeylerinin, bireylerin takımlarının ürünlerini satın alma, takımlarının etkinliklerine katılma gibi davranışsal niyetler üzerinde anlamlı etkilere sahip olduğuna işaret eden sonuçlara ulaşmışlardır. Tüm bu bilgiler ışı̆̆ında, taraftar özdeşlik düzeyinin, bireylerin taraftarı oldukları takımın lisanslı ürünlerini satın alma niyeti üzerinde anlamlı bir etkiye sahip olacağı düşünülmektedir.

$\mathrm{H}_{3}$ : Taraftar özdeşlik düzeyi, lisanslı ürün satın alma niyeti üzerinde pozitif yönde anlamlı bir etkiye sahiptir.

Belirlenmiş olan hipotezler ışığında çalışmanın amacı, lisanslı ürünlere yönelik kalite algısı ve satın alma niyeti üzerinde, taraftarların özdeșleșme düzeylerinin anlamlı bir etkisinin olup olmadığını ortaya koymaktır. Araştırma modeli ve hipotezleri şekil 1'de yer almaktadır.

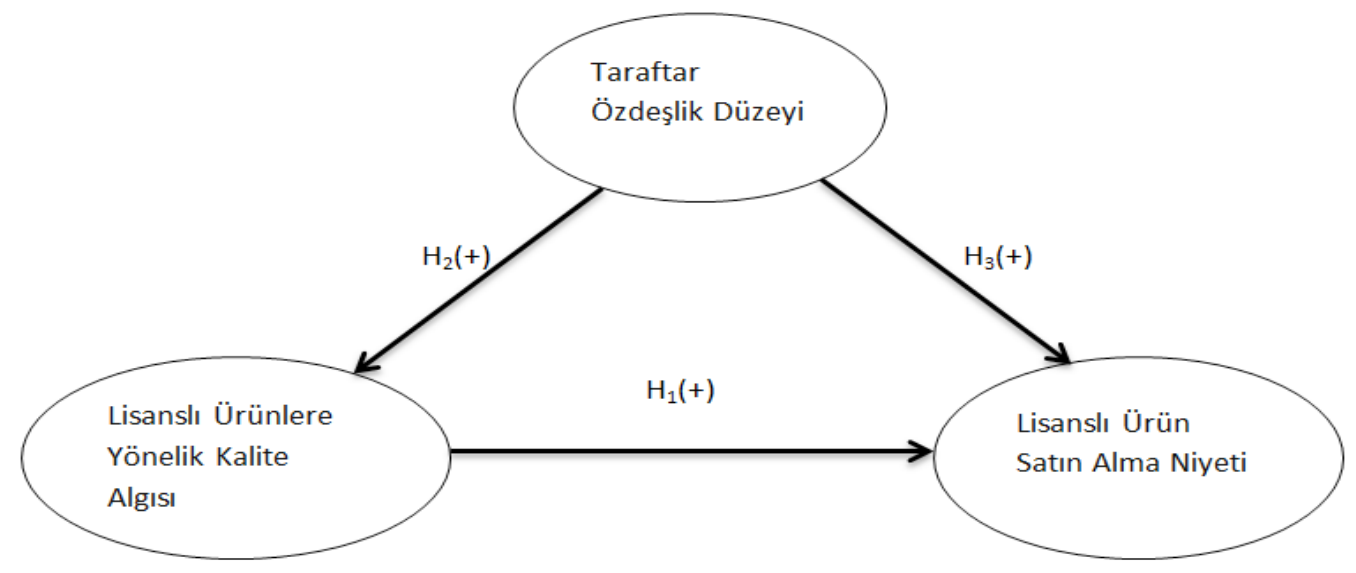

Şekil 1: Araştırma Modeli

\section{ANA KÜTLE VE ÖRNEKLEM}

Futbol maçlarını seyredenlerin önemli bir kısmının gençlerden oluştuğu ve gençlerde bir spor takımının taraftan olmak, bir sporcuya bağlanmak ve tuttuğu takım uğruna kendi kişiliklerini bir kenara bırakmak gibi eğilimler son derece belirgin olduğu (Hoffer, 1988, s.22) bilgisinden yola çıkılarak araştırmanın evreni, Eskişehir Osmangazi Üniversitesi ve Anadolu Üniversitesi'nde öğrenim gören öğrenciler olarak belirlenmiştir.
Bu araştırmada olasılığa dayalı olmayan örnekleme yöntemlerinden kolayda örneklem yöntemi uygulanmıştır. Araştırma kapsamında 332 kişiye anket uygulanmış olup, 18 anket formunun eksik ve hatalı veriler içermesi nedeniyle analizler 314 anket formu üzerinden gerçekleştirilmiştir. Anket formunda 15 ifade yer aldığı göz önünde bulundurulduğunda araştırmanın örneklem büyüklüğünün Stevens (1996, s.72)'ın bağımsız değişken başına on beş (15) denek ile Tabachnik ve Fidell $(2007$, s.123)'in N>50+8M 
( $M=$ bağımsız değişken sayısı) minimum örneklem büyüklüğü kriterlerini (sosyal bilimlerde parametrik analiz için) sağladığı görülmektedir.

\section{VERI TOPLAMA YÖNTEM VE ARACI}

Araştırmanın verileri bırak-al yöntemi ile anket aracılığı ile toplanmıştır. Verilerin toplanmasında iki ana bölümden oluşan anket formu kullanılmıştır. Anket formunda toplam 15 ifade yer almaktadır. Birinci bölümde; taraftar özdeşlik düzeyini ölçmek için Wann ve Branscombe (1993) tarafından geliştirilen, Günay ve Tiryaki tarafından Türkçeleştirilmiş ve geçerlilik ve güvenirliliği test edilmiş olan "Taraftar Özdeşlik Düzeyi" ölçeğinden, kalite algısını ölçmek için Dodds vd. (1991) ile Zeithaml'ın (1998) çalışmalarından derlenmiş ifadeler yer almaktadır. Günay ve Tiryaki'nin (2003) yaptıkları çalışma sonucunda ölçeğin Cronbach Alpha değeri 0.87 olarak bulunmuştur. Ölçeğin Türkiye örnekleminde ve Türkçe olarak geçerlilik ve güvenirliliğinin yeterli olması nedeni ile bu çalışmada Günay ve Tiryaki tarafından Türkçeleştirilmiş olan "Taraftar Özdeşlik Düzeyi" kullanılmasının uygun olacağı düşünülmüştür. Ayrıca katılımcıların taraftarı oldukları takımların lisanslı ürünlerini satın alma niyeti tek bir ifade aracılığıyla ile ölçülmüştür. Ölçeklerin orijinalinde yer alan İngilizce ifadeler tercümeyeniden tercüme yöntemiyle Türkçeleştirilmiş olup, aynı zamanda pazarlama alanında doktora derecesine sahip üç uzman sonrası, pilot uygulama yapılmış ve ölçeğe son şekli verilmiştir. Pilot çalışma 30 katılımcı üzerinde gerçekleştirilmiş olup anlaşılmayan herhangi bir ifadenin olmadığı tespit edilmiștir. Ölçeğin güvenilirliği Cronbach Alpha katsayısı ile ölçülmüştür. Anketin ikinci bölümünde ise demografik özellikleri belirlemeye yönelik sorular yer almaktadır. Ölçekler aracılığıyla görüş ve değerlendirmeler için toplanan veriler "Kesinlikle katılmıyorum... Kesinlikle katılıyorum" şeklindeki 7'li Likert derecelendirme ölçeği ile sayısallaştııılmıştır. Elde edilen veriler AMOS 16.0 paket programı aracılığıyla yapısal eşitlik modellemesiyle analiz edilmiştir.

\section{ARAŞTIRMANIN KISITLARI}

Araştırmanın verileri, zaman kısıtı ve örnekleme ulaşım zorluğundan dolayı kolayda örnekleme yöntemi kullanılarak Eskişehir Osmangazi Üniversitesi ve Anadolu Üniversitesi'nde yaşayan üniversite öğrencilerinden elde edilmiştir. Bu bağlamda araştırma sonuçlarının genellenebilirliği ve dışsal geçerliliği kısıtlıdır.

Araştırmanın bir diğer kısıt ise araştırmanın sadece futbol kulüpleri üzerinde gerçekleştirilmiş olması, diğer spor dallarına ilişkin takımların araştırma kapsamına alınmamış olmasıdır.
Ayrıca araştırma sonuçları, araştırma verilerinin toplanmış olduğu süreç olan Ocak/Şubat-2013 ile kısıtlıdır.

\section{BULGULAR VE DEĞERLENDIRMELER}

Tablo 1'de katılımcıların cinsiyet, aylık gelir ve tuttukları takıma göre dağııımları yer almaktadır.

Tablo 1: Katılımcıların Demografik Özellikleri

\begin{tabular}{|l|c|c|}
\hline & Frekans & Yüzde \\
\hline Cinsiyet & & \\
\hline Erkek & 182 & 58.1 \\
\hline Kadın & 131 & 41.9 \\
\hline Belirtilmemiş & 1 & 0.3 \\
\hline Aylık Gelir & & \\
\hline 750 TL ve altı & 182 & 59.7 \\
\hline $751-1500$ TL & 78 & 25.6 \\
\hline $1501-2250$ TL & 26 & 8.5 \\
\hline 2251 TL ve üstü & 19 & 6.1 \\
\hline Belirtilmemiş & 9 & 2.9 \\
\hline Taraftarı Olunan Takım & & \\
\hline Galatasaray & 126 & 40.1 \\
\hline Fenerbahçe & 85 & 27.1 \\
\hline Beşiktaş & 46 & 14.6 \\
\hline Eskişehirspor & 25 & 8.0 \\
\hline Trabzonspor & 5 & 1.6 \\
\hline Diğer & 27 & 8.6 \\
\hline
\end{tabular}

Tablo 1'e bakıldığında, katılımcıların \%58.1'nin erkek \%41.9'unun ise kadın olduğu görülmektedir. Öte yandan katılımcılar aylık gelirleri bağlamında incelendiğinde, katılımcıların \%59.7'sinin 750 tl ve altı aylık gelire sahip olduğu görülmektedir. Son olarak tuttukları takımlar bağlamında katılımcılar incelendiğinde; katılımcılar arasında en fazla taraftara sahip spor kulübünün Galatasaray olduğu (\%40.1) anlaşılmaktadır.

Tablo-2: Ölçeklerin İçsel Tutarlılığı

\begin{tabular}{|c|c|c|}
\hline & Ifade Sayısı & $\begin{array}{c}\text { Cronbach's } \\
\text { Alpha }\end{array}$ \\
\hline $\begin{array}{c}\text { Taraftar Özdeşlik } \\
\text { Düzeyi Ölçeği }\end{array}$ & 7 &, 954 \\
\hline $\begin{array}{c}\text { Algılanan Kalite } \\
\text { Ölçeği }\end{array}$ & 3 &, 950 \\
\hline
\end{tabular}

Yukarıda yer alan Tablo-2'de araştırmada kullanılan "Taraftar Özdeşlik Düzeyi" ve "Algılanan Kalite" ölçeklerinin içsel tutarlılıklarına ilişkin Cronbach's Alpha değerleri yer almaktadır. Elde edilen değerlerin kabul sınırları içerisinde yer aldığı görülmektedir $(a=0.954 ; a=0.950)$. 
Yapılmış olan doğrulayıcı faktör analizinin sonuçlarında tüm ifadelerin yeterli düzeyde ilgili faktöre yüklendiği görülmüștür. Ölçüm modeline ilişkin elde edilen uyum iyiliği değerlerinin de yeterli düzeyde olduğu $\left(X^{2} / d f=1.952, C F I=0.991\right.$, RMSEA=0.055) gözlemlenmiştir.

Amos 16.0 programı aracılığıyla analize tabi tutulan araştırma modelinin path diyagramı aşağıda yer almaktadır.

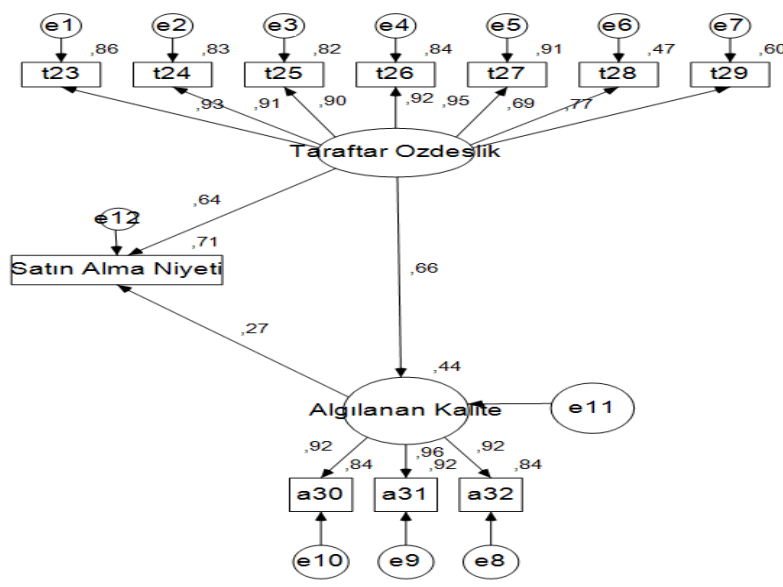

Şekil 2: Araştırma Modeli Path Diyagramı

Yukarıda yer alan araştırma modelinin, uyum iyiliği değerlerinin kabul edilebilir düzeyde olduğu $\left(x^{2} /\right.$ $\mathrm{df}=2.154, \mathrm{CFI}=0.988, \mathrm{RMSEA}=0,061)$ gözlemlenmiştir. Yapısal eşitlik modeli analizinin sonuçları taraftar özdeşlik düzeyinin algılanan kalite ve satın alma niyeti üzerinde anlamlı etkileri olduğunu göstermektedir. Aynı zamanda algılanan kalitenin de satın alma niyeti üzerinde anlamlı bir etkiye sahip olduğu analizler sonucunda ortaya konmuştur. Sonuçlar incelendiğinde Taraftar özdeşlik düzeyinin, algılanan kaliteye oranla, satın alma niyetini açıklamada daha fazla etkiye sahip olduğu görülmektedir. Ayrıca modeldeki bağımsız değişkenlerin Satın Alma niyetindeki değişimin \%71'ini $\left(R^{2}=0,71\right)$ açıklayabildiği görülmektedir. Model kapsamında elde edilmiş olan regresyon katsayıları doğrultusunda oluşturulmuş olan hipotez sonuçları Tablo-3'de yer almaktadır.

\section{SONUÇ, TARTIŞMA VE ÖNERILER}

Çalışmanın sonucunda, taraftar özdeşlik düzeyinin hem lisanslı ürünlerin kalite algısı hem de lisanslı ürünleri satın alma niyeti üzerinde anlamlı etkileri olduğuna işaret eden sonuçlara ulaşılmıştır. Elde edilen sonuçlardan taraftarların tuttukları takımla özdeşlik düzeyinin, taraftarı oldukları takımın lisanslı ürünlerini satın alma niyeti üzerinde anlamlı etkisi olduğuna işaret eden bulgular, Harolle vd. (2010) tarafından yapılmış olan çalışmanın sonuçları
Tablo 3: Hipotez Analizi Sonuçları

\begin{tabular}{|l|c|c|}
\hline \multicolumn{1}{|c|}{ Hipotez } & $\begin{array}{c}\text { Standartlaştırılmış } \\
\text { Regresyon } \\
\text { Katsayıları }\end{array}$ & Sonuç \\
\hline $\begin{array}{l}\mathrm{H}_{1:} \text { Lisanslı ürünlere } \\
\text { yönelik kalite algısı, } \\
\text { lisanslı ürün satın } \\
\text { alma niyeti üzerinde } \\
\text { pozitif yönde } \\
\text { anlamlı bir etkiye } \\
\text { sahiptir.. }\end{array}$ & Desteklendi \\
\hline $\begin{array}{l}\mathrm{H}_{2}: \text { Taraftar Özdeşlik } \\
\text { düzeyi, lisanslı } \\
\text { ürünlere yönelik } \\
\text { kalite algısı üzerinde } \\
\text { pozitif yönde } \\
\text { anlamlı bir etkiye } \\
\text { sahiptir }\end{array}$ & D.661* & Desteklendi \\
\hline $\begin{array}{l}\mathrm{H}_{3}: \text { Taraftar Özdeşlik } \\
\text { düzeyi, lisanslı ürün } \\
\text { satın alma niyeti } \\
\text { üzerinde pozitif } \\
\text { yönde anlamlı bir } \\
\text { etkiye sahiptir. }\end{array}$ & $0.643^{* *}$ & \\
\hline
\end{tabular}

(Not: ${ }^{* *} \mathrm{p}<, 01$ )

ile paralelliksergilemektedir. Bir diğer taraftan, taraftarı olunan takımın lisanslı ürünlerine ilişkin kalite algısının, taraftarı olunan takımın lisanslı ürünlerini satın alma niyeti üzerinde anlamlı etkisi olduğuna ilişkin elde edilen bulgular literatürde yer alan ilgili çalışmaların sonuçlarını (Boulding vd., 1993; Parasuraman vd., 1996; Tsiotsou, 2006) desteklemektedir. Öte yandan taraftarı olunan takımın lisanslı ürünlerine ilişkin kalite algısı üzerinde, taraftarın özdeşlik düzeyinin etkili olduğuna işaret eden sonuçların literatüre anlamlı katkılar sağlayacağı düşünülmektedir.

Çalışmanın literatüre anlamlı katkı sağlayabileceği düşünülen bir diğer sonuçise, satınalma niyetiüzerinde taraftarın özdeşlik düzeyinin, algılanan kaliteye oranla daha etkili olmasıdır. Bu sonuç literatürde yer alan spor taraftarının satın alma davranışlarının irrasyonel olabildiğine ilişkin çalışmaları (Pierpoint, 2000; Banks, 2002) destekler niteliktedir. Kwon ve Armstrong (2006) yaptıkları çalışmada benzer çıkarımlara işaret eden bulgulara ulaşmışlardır. Çalışma sonuçları taraftarların lisanlı ürünleri fonksiyonel özelliklerinden çok sembolik değerleri için aldıklarını göstermektedir. Sonuç olarak çalışmamızın, taraftarların lisanslı ürün satın alma davranışın irrassyonel olduğuna ilişkin sonuçları da literatürde yer alan ilgili çalışmaların sonuçları ile paralellik göstermektedir. 
Yapılmış olan bu çalışmanın ışı̆̆ında, spor kulüplerinin önemli bir gelir kaynağı olan lisanslı ürünlerinin satın alım kararlarının, taraftarların ilgili ürünlerin kalitelerinden ziyade, spor kulübü ile aralarında geliştirmiş oldukları duygusal bağlar neticesinde verildiği çıkarımında bulunulabilir. Nitekim spor kulüplerinin daha fazla gelir elde edebilmek adına lisanslı ürünlerini daha kaliteli ürettirmekten ziyade, taraftarı ile arasında duygusal bağları geliştirmeye yönelik pazarlama stratejileri uygulamalarının daha faydalı olacağı düşünülmektedir.

Çalışmada ortaya konmuş olan model çerçevesinde, lisanslı ürünleri satın alma niyetindeki değişimin \%74'lük bir kısmı açıklanabilmektedir. Bu sonuçtan hareketle, taraftarların takımlarıyla olan özdeşleşme düzeyleri ve lisanslı ürünlere yönelik kalite algılarının satın alma niyetini anlamlı bir şekilde açıkladığı söylenebilir.
Illeride yapılacak olan çalışmalarda, farklı spor dallarında faaliyet gösteren spor kulüplerinin benzer bir çalışma kapsamında ele alınmasının literatüre anlamlı katkı sağlayacağı düşünülmektedir. Ayrıca, taraftarların taraftarı oldukları takımların ürünlerine yönelik kalite algısı dışında, ilgili ürünlere ilişkin değer algılarının da anlaşılmasının literatüre ve uygulamacılar önemli katkıları olacağı düşünülmektedir. Öte yandan, taraftarların satın alma niyetlerinin bir sonraki aşaması olan satın alma davranışlarının ilgili spor kulüplerinin lisanslı ürünlerinin satılmakta olduğu spor mağazalarında gözlemleneceği nitel bir çalışmanın taraftarların tuttukları takımların lisanslı ürünlerini satın alma davranışlarının daha derinlemesine incelenebilmesi imkanı sağlayabilir. 


\section{SON NOTLAR}

${ }^{1}$ Bu çalışma 12. Ulusal İşletmecilik Kongresinde sunulmuş olan bildirinin genişletilmiş halidir.

\section{KAYNAKLAR}

Aaker, D.A. ve Jacobson, R. (1994) "The Financial Information About Content of Perceived Quality" Journal of Marketing Research, 31:191-202.

Argan, M. ve Katırci, H. (2008) Spor Pazarlaması, 2. Basım, Ankara, Nobel Yayınları.

Aşçı, A. (2009) "Futbolcularda Kuvvet Performansının Değerlendirilmesi” 3.Ulusal Futbol ve Bilim Kongresi Bildiri Kitabı.

Aycan, A., Polat, E. ve Uçan, Y. (2009) "Takım Özdeşleşme Düzeyi ile Profesyonel Futbol Müsabakalarına Seyirci Olarak Katılım Kararını Etkileyen Değişkenler Arasındaki İlişkinin İncelenmesi" Spormetre Beden Eğitimi ve Spor Bilimleri Dergisi, 7 (4):169-174.

Aytaç, K.Y.(2009) “Taraftarların Spor Kulüplerindeki Lisanslı Ürün Pazarlama Faaliyetlerine İlişkin Satın Alma Tutumlarının İncelenmesi” Yayımlanmamış Doktora Tezi, Ankara Gazi Üniversitesi Sosyal Bilimler Enstitüsü.

Banks, S. (2002) Going Down - Football in Crisis, Edinburgh, Mainstream Publishing Ltd.

Crosby, P. (1979) Quality is Free: The Art of Making Quality Certain, New York, McGraw Hill Custom Publishing.

Bauer, H., Nicola, E,. Stokburger, S. ve Exler, S. (2008) "Brand Image and Fan Loyalty in Professional Team Sport: A Refined Model and Empirical Assessment" Journal of Sport Management, 22:205-226.

Boulding, W., Karla, A., Staelin, R. ve Zeithaml, V.A. (1993) "A Dynamic Process Model of Service Quality: From Expectations to Behavioral İntentions" Journal of Marketing Research, 30(1):7-27.

Burton, R. ve Howard. D. (1999) "Professional Sports Leagues: Marketing Mix Mayhem" Marketing Management, 8(1):36-46.

Daniel, S.M. (1999) "What is The Sports Product and Who Buys It? The Marketing of Professional Sports Leagues" European Journal of Marketing, 33(3):402-419.

Dees, W., Hall, T., Tsuji, Y. ve Bennett, G. (2010) "Examining The Effects of Fan Loyalty and Goodwill on Consumer Perceptions of Brands at an Action Sports Event" Journal of Sponsorship 4(1):38-50.

Demirel, M., Karahan, G.B. ve Ünlü, H. (2007) "Farklı Üniversitelerdeki Spor Taraftarlarının Takımları İle Özdeşleşme Düzeyleri” Niğde Üniversitesi Beden Eğitimi ve Spor Bilimleri Dergisi, 2:76-86.
Dodds, W.B., Monroe, K.B. ve Grewal, D. (1991) "Effects of Price, Brand, and Store Information on Buyers' Product Evaluations" Journal of Marketing Research , 28:309-19.

Erdoğan, İ. (2008) "Futbol ve Futbolu İnceleme Üzerine” İletişim Kuram ve Araştırma Dergisi, 26: 1-58.

Euchner, C.C. (1993) Playing the Field: Why Sport Teams Move and Cities Fight to Keep Them, Baltimore, Johns Hopkins University Press.

European Football Merchandising Report (2010) http://en.sportundmarkt.de/en/news/list/europeanfootball-merchandising-report/european-footballmerchandising-report-2010.html, (06.12.2012).

Ferrand, A. ve Pages, M. (1999) "Image Management in Sport Organisations: The Creation of Value" European Journal of Marketing, 33(3/4):387-401.

Fisher, R.J. ve Wakefield, K. (1998) "Factors Leading to Group Identification: A field Study of Winners And Losers" Psychology and Marketing, 15:23-40.

Garvin, D. (1983) "Quality on The Line" Harvard Business Review, 61:65-73.

Gencer, T. ve Aycan, A. (2008) "Seyircilerin Profesyonel Futbol Müsabakalarına Katılım Kararını Etkileyen Değişkenler Üzerine Bir İnceleme” Ege Akademik Bakı̧, 8(2):771-783.

Gustafson, R. (2001) "Product Brands Look Set to Gain New Advantage” Marketing, 5:1-20.

Giulianotti, R ve Robertson, R. (2004) "The Globalization of Football: A Study in The Glocalization of The 'Serious Life"' The British Journal of Sociology, 55(4):545-568.

Güllü, M. ve Güçlü, M.(2006) “Ortaöğretim Öğrencilerinin Taraftarı Oldukları Spor Takımları İle Özdeşleşmelerinin İncelenmesi” 9. Uluslararası Spor Bilimleri Kongresi Bildiriler Kitabı, 686-689.

Günay, N. ve Tiryaki, Ş. (2003) "Spor Taraftarı Özdeşleşme Ölçeğinin (STÖÖ) Geçerlik ve Güvenirlik Çalışması" Hacettepe Üniversitesi Spor Bilimleri Dergisi 1:14-26.

Harolle, M., Trail, G., Rodriguez, A. ve Jordan, J. (2010)"Conative Loyalty of Latino and Non-Latino Professional Baseball Fans” Journal of Sport Management, 24:456-471. 
Hinckley, S. (2004) "Team Apparel Contracts: Licensing Can Help Maximize Benefits" Athletic Administration, 39,57.

Hoffer, E. (1988) Kesin Inançlilar Kitle Hareketlerinin Anatomisi 4.Baskı, İstanbul, Akran Yayınları.

Jacoby, J. ve Olson, J. (1985) Perceived Quality, Lexington Books, Lexington, MA.

Kolah, A. (2005) Maximizing Revenue from Licensing and Merchandising, Sport Business Group, London.

Kwak, D.K. ve Kang, J. (2009) "Symbolic Purchase in Sport: The Roles of Self-Image Congruence and Perceived Quality” Management Decision, 47(1):85-99.

Kwon, H. (2002) "An Investigation of The Pschosocial and Financial Factors Influencing The Impulse Buying of Sport Team Licensed Merchandise" Basılmamış Doktora Tezi, The Ohio State University.

Kwon, H. ve Armstrong, K.L. (2006) "Impulse Purchases of Sport Team Licensed Merchandise: What Matters?” Journal of Sport Management, 20:101-119.

Mitra, D. ve Golder, P.N. (2006) "How Does Objective Quality Affect Perceived Quality? Short-Term Effects, Long-Term Effects and Asymmetries" Marketing Science, 25:230-47.

Monroe, K. ve Krishnan, R. (1985) "The Effect of Price on Subjective Product Evaluations" Olson et al (eds.) Perceived Quality, Lexington, Lexington Books.

Parasuraman, A., Zeithaml, V. ve Berry, L. (1996) "The Behavioral Consequences of Service Quality" Journal of Marketing, 60:31-46.

Pierpoint, B. (2000) "Heads above Water: Business Strategies for a New Football Economy" Garland et al. (eds.) The Future of Football - Challenges for the TwentyFirst Cen-tury, London, Frank Cass Publishers.

Shank, M.D. (1999) Sport Marketing, Upper Saddle River, NJ, Prentice Hall.
Spears, N. ve Singh, S.N.(2004) "Measuring Attitude Toward The Brand and Purchase Intentions" Journal of Current Issues and Research in Advertising, 26(2):53-66.

Stevens, J. (1996) Applied Multivariate Statistics for The Social Sciences, 3rd Edition, New Jersey, Mahwah, Lawrence Erlbaum.

Tabachnick, B.G. ve Fidell, L.S. (2007) Using Multivariate Statistics, 5th Edition, Boston, Pearson Education.

The National Post(2004) "Real Madrid Claims Top Spot With Euros 138M in Sports Marketing" The National Post , FP3, 2004/7/20.

Tsiotsou, R. (2006) “The Role of Perceived Product Quality and Overall Satisfaction on Purchase Intentions" International Journal of Consumer Studies, 30:207-17.

Underwood, R., Bond, E. ve Baer, R.(2001) Building Service Brands Via Social Identity: Lessons From The Sports Marketplace, Journal of Marketing Theory \& Practice, 9(1):1-13.

Yavaş, Ö. (2005) "Sporun Ekonomi İçerisindeki Yeri Ve Spor Pazarlama: Üç Büyük Spor Kulübünde Uygulamalı Bir Araştırma” Yüksek Lisans Tezi, Edirne Trakya Üniversitesi Sosyal Bilimler Enstitüsü.

Walvin, J. (2001) The Only Game: Football in Our Times, London, Pearson.

Wann, D.L. (1997) Sport Psychology, New Jersey, Prentice Hall, Inc.

Wann, D.L ve Branscombe, N.R. (1993) "Sports Fans: Measuring Degree of Identification With Their Team" International Journal of Sport Psychology, 24(1):17.

Wann, D., Walker, R., Cygan, J., Kawase, I. ve Ryan, J. (2005) North American Journal of Pyschology, 7(3):361366.

Zeithaml, V. (1998) "Consumer Perception of Price Quality and Value: A Means End Analysis and Synthesis of Evidence" Journal of Marketing, 52:2-22. 
